\title{
Reflections on the financial innovation of China's capital market from the perspective of economic transformation
}

\author{
Zhixu Mao ${ }^{1, *}$ \\ ${ }^{1}$ International college, Guangxi university, Nanning, Guangxi, 530004, China
}

\begin{abstract}
General Secretary Xi Jinping said at the Fifth Plenary Session of the 19th CPC Central Committee that "the new development concept is a systematic system. In the perspective of economic transformation, we should do a good start and a good step in development. Under the premise of comprehensive thinking of China's capital market finance, adhere to the reform and innovation development, green coordinated development, resource sharing development, political open development "" In the perspective of economic transformation, Party members and cadres at all levels should adhere to the implementation of the new development concept, pay attention to the common prosperity, to achieve the modernization process of continuous development. To address the wealth gap between urban and rural areas, between regions and between populations." This article is written after carefully studying the important speeches of General Secretary Xi Jinping and consulting a large number of relevant reference materials. This paper deeply reflects on the financial innovation characteristics of the capital market in China's economic transformation period, and puts forward new suggestions on the development of economic transformation, aiming to help some government functionaries improve their understanding of the capital market.
\end{abstract}

\section{Introduction}

In recent years, China has achieved the miracle of reform and opening up by relying on the economic growth mode of domestic investment and foreign export. In October 2020, it was announced that China had officially completed the national poverty alleviation. Under the correct leadership of the CPC Central Committee, China's economic development has been greatly improved. However, this is also due to the extensive development mode, the increasingly complex international situation, and the invasion of the ideology of globalization into China's traditional culture. If we only rely on the past internal high investment, high consumption of economic growth situation, it is difficult to meet the future development needs of China. To this end, we should focus on tapping domestic demand, increasing people's income level, and promote the transformation of the form of economic growth into intensive. At the Fifth Plenary Session of the 19th CPC Central Committee, General Secretary Xi Jinping clearly proposed that "our functional departments should transform the traditional economic growth mode, eliminate the poverty gap, ensure that funds are invested in entities, and alleviate the financing difficulties of the real economy". And China's capital market is the best economic financing channel for private enterprises. Under the special background of economic transformation, capital market, as the main component of China's economy, should formulate financial innovation strategies according to the actual development situation.

\section{Development status of China's capital market}

\subsection{The overall situation of the capital market}

According to the data disclosed by the National Finance Bureau, the Labor Bureau, the Bureau of Statistics and the Tax Bureau, China's capital market has made great achievements. In terms of quantity, China has established its own capital trading market. By the end of 2020, China had two trading houses, namely the Shanghai Stock Exchange and the Shenzhen Stock Exchange. Four futures exchanges, namely Dalian Commodity Exchange, Shanghai Futures Exchange, Zhengzhou Commodity Exchange and China International Monetary Exchange; There are more than 3,520 listed companies and more than 320 million effective accounts for investors. There are 78 varieties listed on the four futures exchanges. The total assets of 100 securities companies exceed 3 trillion RMB and the net assets exceed 100 million RMB [1]. If standing on the development of innovation perspective, the stock ownership reform basic has been completed, and under the leadership of the general secretary Xi Jinping has solved the problems left over by history, for Treasury bonds futures market development way for roads, sped up the pace of digital currency development, realize the rationalization of financial resources allocation of capital market in China, has changed the traditional financing system and financing in our country, the entity economy

\footnotetext{
*Corresponding author: 841268573@qq.com
} 
development of our country has played a positive role. Moreover, driven by the strong development of domestic economy, China's foreign trade investment has been increasing year after year [2].

\subsection{Main achievements of financial innovation}

In recent years, under the correct leadership of General Secretary Xi Jinping, China's country's financial system, market structure, and financial financing tools have undergone fundamental innovation and reform. In terms of the financial system, China's capital market has completed the reform of equity distribution through the securities market, gradually dealing with the issue of securities issuance and circulation, and gradually integrating with the international economy. In terms of market structure, my country has gradually completed the establishment and transfer system of the stock market main board, growth enterprise board, and small and medium-sized board, and has a multi-level capital market system such as commodities, finance, transportation, and technology [3]. In terms of financial financing tools, the stock market business has gradually become more innovative. The surrounding stock market, fund varieties, futures trading, and property market investment have derived a variety of financial products. In particular, property market investment has become the most popular financial product at the moment [4].

\section{The necessity and cause of financial innovation in economic transition period}

\subsection{The necessity of financial innovation in economic transition period}

The construction of financial structure is the core of China's economic development, and economy determines the direction of financial development. Finance must also serve the needs of economic development. In the era of economic transformation, the innovation of financial system structure is the main way to promote economic development. The biggest advantage of innovation and development is that it can improve the working efficiency of financial enterprises, enable all industries to remain in a state of rapid development, enhance the competitiveness of China's export products, stimulate domestic consumption, and then improve the living standards of Chinese people and promote the rapid development of China's society. Only through financial innovation can economic development become more permeable, influential and acting force, achieve the great goal of "common prosperity" as soon as possible, and make finance become the main driving force of economic development [5].

\subsection{The Causes of Financial Innovation in the Period of Economic Transition}

First, after the economic containment of China by the
United States in 2019, it has been proved once again that China's inward investment and consumption have reached a bottleneck. The coastal model, which relies heavily on external preferences from foreign countries, cannot be sustained under the influence of politics. Economic development and transformation are an inevitable trend. In western countries, led by the United States, crazy containment for China's economy, science and technology, China's economy must maintain healthy development through reform and innovation mode, solve the single mode of economic development in our new system and mechanism innovation, improve to the private sector support, rapid economic development in an effort at the same time vigorously develop science and technology, get rid of the foreign technology blockade to our country as soon as possible. Among the top developed countries in the world, those countries with a relatively high degree of capital market innovation and strong domestic demand and consumption capacity have had a relatively high economic development speed, national welfare construction speed, and average living standard [6]. Second, China's capital market is different from the capital markets of other capital countries, and the socialist capital market with Chinese characteristics needs to further extend its institutional characteristics to further deepen the reform of the capital market. Capital market in China is gradually developed along with the implementation of the strategy of reform and opening up, after several years of development, our country capital market as well as the special function and mechanism, in promoting the economic system reform and the development of national economy plays an important role in the process of structural adjustment, in the economic transformation period, we should believe that regulating the operations of the capital market itself. Third, reform and innovation of capital market is an inevitable choice in the period of economic transformation. Since China's capital market is still in the developing stage, its internal structure and types of financial products are quite different from those of developed countries. The hierarchical prediction structure, product analysis structure, and related laws and regulations are not perfect. Financial innovation, as an integrated and optimized combination of various resources in the financial field, is extremely conducive to improving the efficiency of financial investment in the capital market, reducing investment risks to a certain extent, and maintaining the stability of capital market operations. Therefore, financial innovation in the economic period has an important impact on my country's economic development [7].

\subsection{The objective demand of capital market economy development}

Recalling the history of China's economic development, China once launched foreign exchange futures, national debt and other economic derivatives in 1990, but due to the overall economic environment is not mature, the relevant product design defects, financial supervision is not perfect and other comprehensive reasons, finally stopped in 1995 successively. However, with the 
implementation of China's reform and opening up policy, China's capital market began to take root and sprout, and gradually grew into a towering tree from 2001 to 2010 . During this period, the development and reform of the capital market never stopped. For example, the reform of equity allocation was officially started in 2004. Margin and short selling business was established in 2006; Launched in 2010. However, compared with developed countries, the development of China's capital market still has a lot of room for reform, and its financial products still can not meet the participation needs of the Chinese people. If you want to realize the wealth of people through securities and stocks, there is still a long way to go. In combination with the specific situation of China, from the perspective of financial innovation products, China's financial market still objectively exists the risk of fraud by investors and financial crimes committed by speculators through management loopholes [8].

\section{The key point of innovation and development of capital market in the period of economic transformation}

\subsection{Specific problems existing at the present stage}

Due to the problems in China's socialist system, China's capital market is still in its primary stage after a long period of development, and there are still some problems in the management of the capital market. First of all, there is a shortage of financial products at the present stage. There are no financial financing tools or financial products for small and medium-sized enterprises, agriculture and other industries, and there is a lack of guidance tools derived from the real economy in the economic transition period [9]. Although financial markets have been in China there are many financial products, but the concentration of these types of financial products, anti-risk ability is poor, if a financial storm in 2008, will be unimaginable damage, and lack of the first pillar industry, the second pillar industry vigorously support, this leads to bond products is not enough, not suitable for long-term investment.

At the present stage, stock futures, stock options and national debt futures are all to be launched in China's capital market except stock index futures. Moreover, the futures market lacks coordination and authority and scientific and effective investment management, so it is impossible to continuously promote the scale development of the futures market. At the same time, the capital market regulation and financial innovation are not highly consistent. In terms of the regulatory concept and relevant legal provisions, China's attitude towards the capital market is always in the state of risk prevention and control. In terms of regulatory means, administrative means are more than market self-regulation means, which is not conducive to the function of the capital market mechanism. In addition, the relevant departments lack unified management standards and regulatory objectives, leading to excessive duplication of regulatory work, waste of regulatory resources, and more seriously, restricting the innovative development of the capital market [10].

\subsection{Key points of capital market innovation}

In view of the development status of China's capital market, financial innovation in capital market should be promoted from two aspects: first, the innovation of financial products in capital market. According to the actual needs of China's economic transformation and development, on the basis of meeting the "sustainable development strategy" and "rural agricultural transformation strategy", financial derivatives should be innovated. If practical problems encountered in economic transformation are solved, financial innovative products can improve risk avoidance and capital profitability. Second, financial system innovation. At present, the financial management system of the capital market has been unable to meet the needs of China's economic development. In order to ensure the large-scale and systematic development of financial assets, ensure the more stable development of China's capital market, and improve the efficiency of China's enterprise reform. Relevant national departments should reform the original capital market management methods, reduce the influence of administrative means on the capital market, open the domestic financial market, and promote the domestic commodity manufacturers to enhance their competitiveness.

\section{Based on the background of economic transformation in China's capital market financial products innovation ideas}

\subsection{Industrial Investment Fund for Transformation and Upgrading}

Government functional departments should take advantage of the opportunities of economic transformation to design transformation industry investment funds, promote the implementation of China's economic transformation and upgrading policies, and convert social capital and various resources into production investment capital. In short, more investment funds can be integrated into the capital market through the judgment of the investment direction of industrial funds, the mode of production organization, financial investment channels and the control of risk avoidance at each stage.

\subsection{High yield bond}

Promoting the issuance of high-yield bonds and raising the threshold for the purchase of high-yield bonds can solve the financing difficulties of SMEs. We will encourage derivative financial instruments in the capital market to serve the real economy, increase the proportion of direct financing in the whole society, reduce risks in the banking system, and give full play to the real value of the bond market. In our country securities market and the stock market under the condition of relative lag, develop high- 
yield bonds is also a kind of effective method to implement financial services, more conducive to enterprise financing demand, at the same time also can issue bonds, to increase people's wealth and income, widen the channels of private investment funds, but it is worth noting that high-yield bonds can be a lot of junk bonds, these junk bonds not only confuse people line of sight, small and medium-sized enterprises and investment would also reduce the people's trust for the government's securities regulator, so relevant departments should according to the requirements of the economic transformation development depth reform of the securities regulatory authority, It restricts its administrative power and focuses its management on strengthening the "quality inspection" of securities.

\section{Conclusion}

In a word, under the background of economic transformation, financial innovation in China's capital market is urgent. However, the financial innovation work needs a long period of experience accumulation, continuous gradual progress, and the establishment of a scientific and reasonable financial risk avoidance system. Prevent other countries to our economic sanctions and scientific and technological blockade, we must avoid the subprime crisis. As for the innovation work of financial products and futures and bonds, China must learn from the relevant experience of developed countries, and combine it according to the actual situation of China to deepen the intensity of financial reform. Only in this way can we give better play to the impetus of financial innovation for China's economic development, improve the living standard and quality of Chinese people, and realize the socialist development goal of "common prosperity" as soon as possible.

\section{References}

1. Wang Manyi, Zhen Hanlei. (2018) The Heterogeneous Impact of Financial Development on Economic Growth Driven by Innovation -- Also on the Transduction Role of Technology. Research in Institutional Economics, 01:139-163.

2. Sun Xuejiao, Zhu Yifan. (2019) Research on the Synergetic Development Mechanism of Technological Innovation and Financial Services -- A Multi-case Analysis Based on the Evolution Perspective of China's Technological Finance Platform. Research in Financial Development, 01:7379.

3. Meng Fenglin, Tian Zengrui, Jia Qiaoping, et al. (2019) Study on the evolution process, experience and policy of venture capital system in China from the perspective of evolutionary economics. Southwest Financial, 07:3-10.

4. Liu Chao, Ma Yujie, Shi Tongfei. (2019) Exploration of China's Real Economy Development Dilemma and New Driving Forces -- Based on the Perspective of Financial Innovation and Technology Innovation.
Journal of Tianjin University of Finance and Economics, 12:3-19.

5. Pang Min, Xia Zhoupei. (2020) The Impact Mechanism and Effect Analysis of Financial Innovation on Industrial Structure Upgrading -Based on the Analysis of Mediating Effect and Spatial Effect. Industrial and Technical Economics, 09:32-40.

6. Liu Xiaochun, Jiang Jingshu. (2019) The Limitation and Innovation of China's Capital Market Dispute Resolution Mechanism -- Based on the Practice of Shenzhen Securities and Futures Industry Dispute Resolution Center. Financial Law Court, 02:48-65.

7. Zhou Xiaoling, Gong Xinshu. (2020) The influence of government finance and financial market on regional independent innovation capability. Journal of South China Agricultural University (Social Science Edition), 019:84-95.

8. Liu Ti. (2020) Capital Market Supply Shortage, Social Welfare and Economic Growth -- An Empirical Study Based on China's A-share Market. Shanghai Finance, 03:4-10.

9. Zhang Yu. (2020) The impact of multi-level capital market on innovation of science and technology firms: A case study of Weifang City, Shandong Province. Times Financial, 33:66-68

10. Zhan Hailin, Gu Ziqiang. (2020) Strategic research on technology-oriented enterprises' entry into capital market under the background of the establishment of "science and technology innovation board" -- A case study of W Company. Modern Marketing (Business Edition), 08:54-55. 